\title{
固体表面上でのポルフィリン分子の 選択的自己組織化
}

\author{
横山 崇・横山士好* ·上門敏也* \\ 奥野好成 $*$ 益子信郎* \\ 物質・材料研究機構 ナノマテリアル研究所－ - 463-0003 愛知県名古屋市守山区下志段味 2268-1 \\ “通信総合研究所 関西先端研究センター 画 651-2401 兵庫県神戶市西区岩岡町岩岡 588-2
}

(2002 年 6 月 24 日受理)

\section{Selective Assembly of Porphyrin Molecules into Supramolecular Aggregates on a Surface}

Takashi Yokoyama, Shiyoshi Yokoyama *, Toshiya KamiKado*,

Yoshishige OKUNO* and Shinro MASHIKO*

National Institute for Materials Science, 2268-1 Shimoshidami, Moriyama-ku, Nagoya, Aichi 463-0003

${ }^{*}$ Communications Research Laboratory, 588-2 Iwaoka, Nishi-ku, Kobe, Hyogo 651-2401

(Received June 24, 2002)

The rational construction of desired molecular nanostructures should be required to realize molecular nanodevices, ideally with these structures supported on suitable substrates. We report the formation of surface-supported supramolecular structures whose size and aggregations patterns are rationally controlled by using selective and directional intermolecular interactions between cyanophenyl substituents. Using low-temperature scanning tunneling microscopy and molecular orbital calculations, we have analyzed the conformation and arrangement of adsorbed porphyrin molecules on $\mathrm{Au}(111)$ surface. In case of cyanophenyl-substituted porphyrins, monomers, trimers, tetramers, or extended wire-like structures is selectively formed on the $\mathrm{Au}(111)$ surface by modifying substituents. These structures should be induced by local dipole-dipole interaction between cyanophenyl substituents. Our findings indicate that the rational design and construction of surface-supported supramolecular architectures will be allowed by introducing non-covalent interactions.

\section{1.は じめに}

半導体デバイスの微細化限界に伴う次世代のナノテク ノロジー技術として, 分子の機能性を利用した分子ナノ デバイスが期待されている1,2)。有機分子の多機能性を 利用しようとする場合, 兴のコンフォメーションや組織 化構造などを基板上で制御することが重要である。近年， 走査型プローブ顕微鏡 (SPM) 技術の向上により，ナノ スケールの巨大分子もしくは分子集合体の微細構造まで 観察できるようになってきた ${ }^{3 \sim 6)}$ 。特に, 有機分子は単

E-mail: YOKOYAMA.Takashi@nims.go.jp
独で機能を有するだけでなく，個々の部品分子を組織化 することで単独の分子では持たなかった新しい機能を作 り出すことが可能であり，光の機能性を制御することで 新規分子デバイスが期待される。例えば, DNAやたん ぱく質に代表される生体システムも個々の部品分子の組 織体であり，光の多樣な組み合わせによって高度な機能 を実現している。水素結合に代表される非共有性結合を 積極的に利用し, 人工的に分子組織体を制御する研究は “超分子化学”と呼ばれ, 複杂隹な分子組織体が制御され ている7)。しかしながら, 弚れらの研究は主に溶液中で 行われており，SPMなどを使った直接観察の手段が無 い上に , デバイス化に最適な基板上にどうやって配置す 
るかという問題点がある。

本稿では, 機能性ポルフィリン分子の $\mathrm{Au}(111)$ 表面 上での吸着構造を低温・走査型トンネル顕微鏡 (STM) で明らかにし,さらにポルフィリン分子に双極子相互作 用を持つシアノ基を化学合成で導入することで, 個々の 分子を基板表面上で組み上げる試みを行った。

\section{2. ポルフィリン分子と乥の非平面化吸着}

ポルフィリン分子は, 機能性分子として最も多く研究

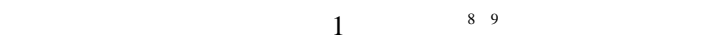

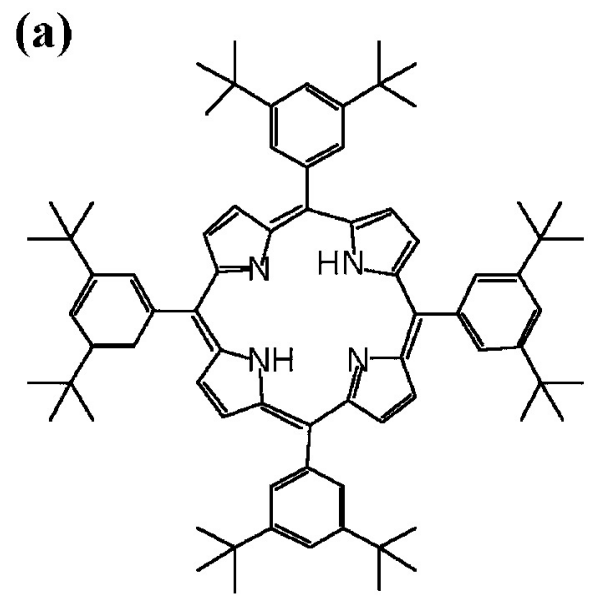

(b)

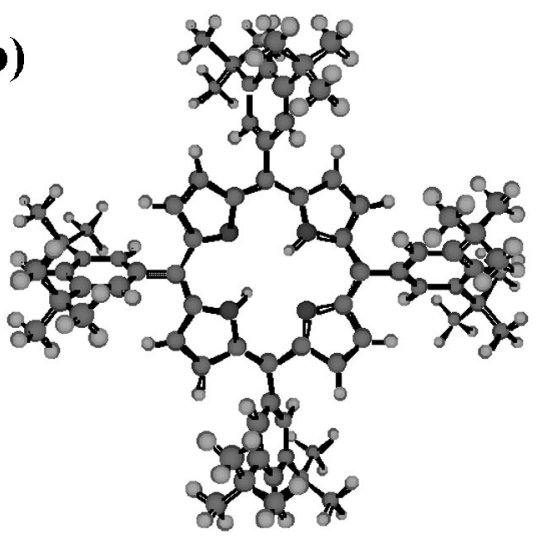

Fig. 1 (a) A structure of TBPP, which includes the central porphyrin and four di-tertiarybutylphenyl substituents. (b) Calculated conformation of TBPP, obtained from the semiempirical molecular orbital method. The $60-90^{\circ}$ rotations of phenyl-porphyrin bonds results from steric hindrance between the phenyl and porphyrin rings.
然界でも存在し，光合成をつかさどるクロロフィル , 赤 血球, へモグロビン, 乥してビタミン $\mathrm{B}_{12}$ などもポルフ イリンが基本骨格となっている。特に，中心にさまざま な金属を配位することができ，光の種類によって機能性 を制御できることが知られている。本研究で用いたポル フィリンの基本構造は, Fig. 1 (a) に示すようにポルフ イリン環を中心に 4 つのブチルフェニル基を付加してお り, TBPP (Tetrakis-(di-tertiarybutylphenyl) porphyrin) と 呼ばれる ${ }^{10)}$ 。半経験的分子軌道法計算によると, TBPP 分子の安定構造では Fig. 1 (b) のようにブチルフェニ ル基がポルフィリン環に対して直交するように回転する ため, 基板上に吸着させても絶縁性のブチル基がスペー サーとして機能し , ポルフィリン環が基板表面と直接結 合することを妨げることが期待される ${ }^{4,5,10)}$ 。つまり， ポルフィリンが持つ機能性を基板上で維持できる可能性 を持つ。さらにこの分子は，熱的に非常に安定であり， Kセルを用いた真空蒸着を行うことができる。

今回基板として用いた $\mathrm{Au}(111)$ 表面は, マイカ上に 金を真空蒸着することによって作成し，超高真空チャン バー内でスパッタ・アニールを行うことで清浄表面を得 た。Fig. 2 は，63 K にて得られた Au(111) 清浄表面の 超高真空・走査型卜ンネル顕微鏡 (STM)像である。STM 像に示すように，この基板表面はペアになったストライ プがジグザグ状に折れ曲がり ““ヘリングボーン構造” と呼ばれる特徵的な超構造を示す。この超構造の詳細は 原著論文を参照されたいが, 重要なのはへリングボーン 構造の変曲点の一部に局所的な転位が存在し, 優先的な 吸着サイトとなることである。

まず最初に，この基本分子である TBPPが $\mathrm{Au}(111)$

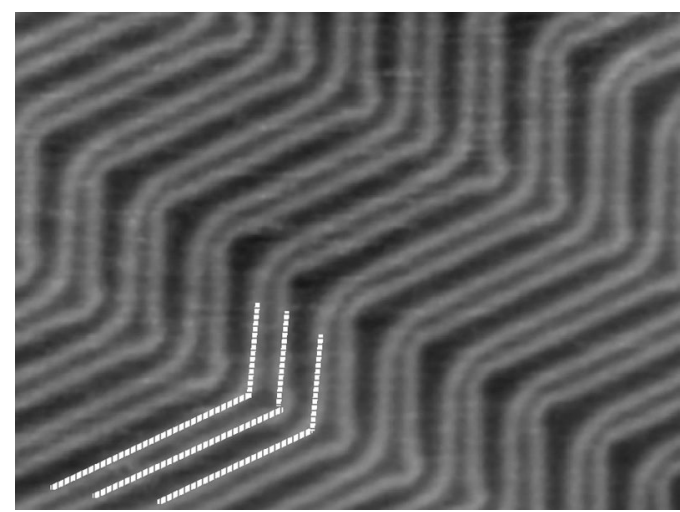

Fig. 2 STM image at $63 \mathrm{~K}$ of the $\mathrm{Au}(111)$ surface, in which bright stripes are associated with domain walls between fcc and hcp stackings, as indicated by dashed lines, and the herringbone patterns are formed by periodic rotations of the uniaxial domains. 
表面上でどのような吸着構造をとるかを調べた ${ }^{11)}$ 。全て の実験は超高真空下で行い, 室温の基板上に分子を蒸着 させた後 , すぐに試料を低温ステージに移動し STM 観 察を行った。また,トンネル電流を通常よりも 3 桁程度 低い $5.0 \mathrm{pA}$ に設定することにより，STM 探針の影響を 最小限に抑えている。Fig. 3 (a) は, 微量の TBPP 分子 を蒸着した時に得られた低温 STM 像である。この表面 では単一分子が表面上に分散し, 規則正しく配列してい ることがわかる。これは, 個々の分子がヘリングボーン 構造の変曲点に選択的に吸着しているためであり，これ によって単一分子状態での高分解能 STM 観察が可能に なる。

Fig. 3 (b) は単一状態で得られた TBPP 分子の高分解 能 STM 像であり，中央付近の 2 つに分裂した楕円状の 輝点と乥れを取り囲む明るい輝点とやや暗めの輝点のペ アに分類される。分子軌道計算によって得られた TBPP 分子のサイズと比較することにより，4組の輝点はブチ ル基 , 楕円状の輝点はポルフィリン環に対応すると考え られる。また , ブチル基がペアになって観察されること から, 安定構造 (Fig.1 (b)) のようにフェニル基はポ ルフィリン環に対して直交せずに , 共平面に近くなって いるといえる。実際に分子構造と STM 像を比較するこ とによって , ポルフィリン環とフェニル環の 2 面角は約 $20^{\circ}$ であり，隣り合ったフェニル基が互い違いの方向で 回転していることが明らかになった。これはポルフィリ ン環とフェニル基の単結合による回転自由度のためであ り, 明るい輝点と暗めの輝点は, 弚れ光れせり上がった ブチル基と基板と接触しているブチル基と考えられる。 Jung $^{4,5)}$ らの研究によって, TBPP 分子におけるフェニル 基の回転角度は金属基板構造に依存することが知られて いる。つまり，フェニル基が回転することで，下地の原 子配列にうまく適合した吸着構造 (コンフォメーション) を形成すると考えられる。

TBPP 分子の高分解能像でさらに興味深いのは, ポル

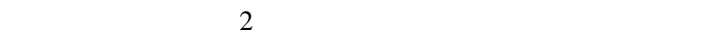
ある。しかしながら STM 像の場合, 弚れが実際の原子 構造によるものなのか, 電子状態によるものなのか実験 的に区別することは容易ではない。乥こで我々は，半経 験的分子軌道計算を行うことによって分子構造のフェニ ル基の回転による影響を調べた。実際の実験結果と合う ように 2 面角を $20^{\circ}$ に固定して構造最適化を行った結果 が，Fig. 4 である。この場合，フェニル基とポルフィリ ン環の間に立体障害が起こり，ポルフィリン環を構成す る4つのピロール環が互い違いに上下するような鞍型に 非平面化した。このことから，STM 観察されたポルフ イリン環の内部構造は光の非平面構造によるものと考え (a)

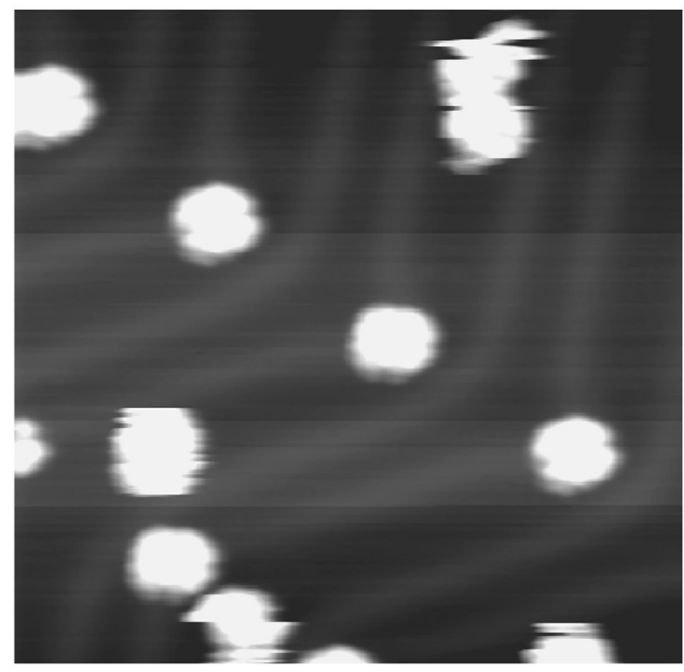

(b)

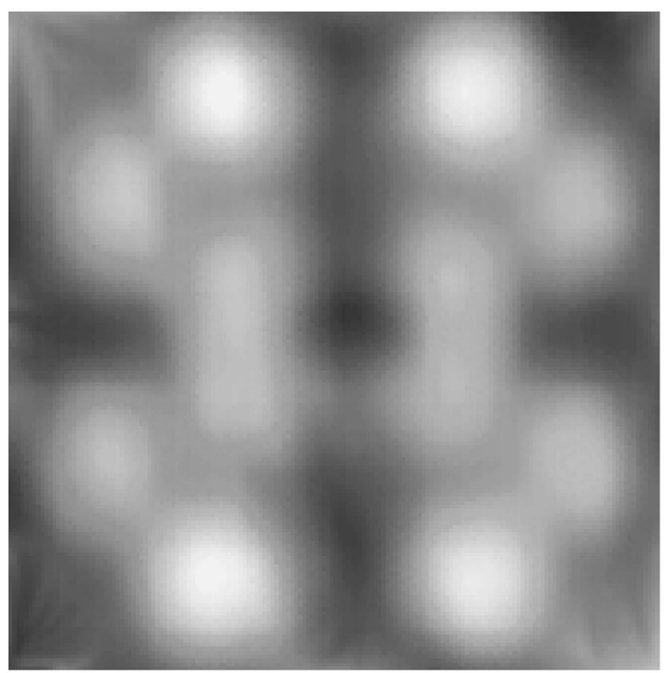

Fig. 3 (a) STM image $(20 \mathrm{~nm} \times 20 \mathrm{~nm})$ at $63 \mathrm{~K}$ of TBPP molecules adsorbed on the $\mathrm{Au}(111)$ surface. A regular array of the single molecules results from preferential adsorption at the elbows of the herringbone patterns. (b) High-resolution STM image $(2.1 \mathrm{~nm} \times 2.1 \mathrm{~nm})$ at $63 \mathrm{~K}$ of a single TBPP molecule, which is composed of four paired lobes surrounding two oblong protrusions.

られ，楕円状の輝点はせり上がったピロール環に対応し ていると思われる。比較のため, STM 像で得られた輝 点を Fig. 4 (a) に重ねた。これらのことから $\mathrm{Au}(111)$ 表面における TBPP 分子の吸着構造は, 表面構造 (周期) 


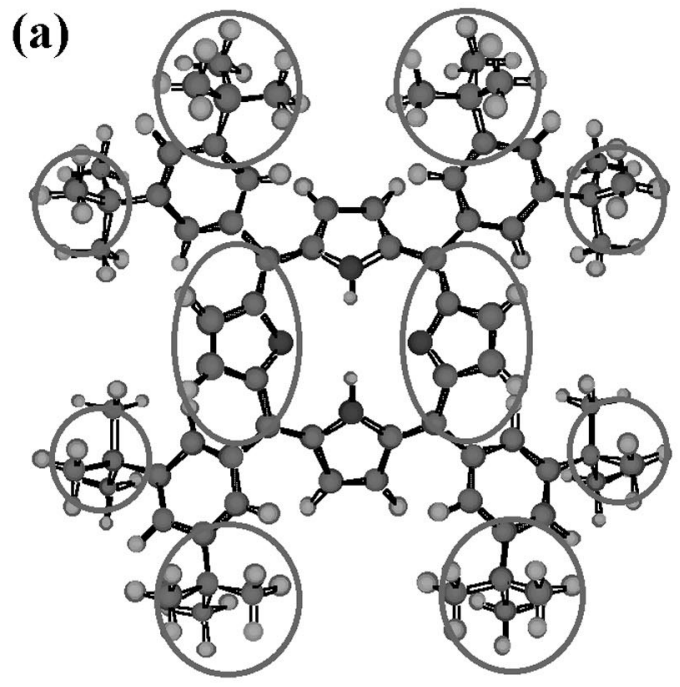

(a)

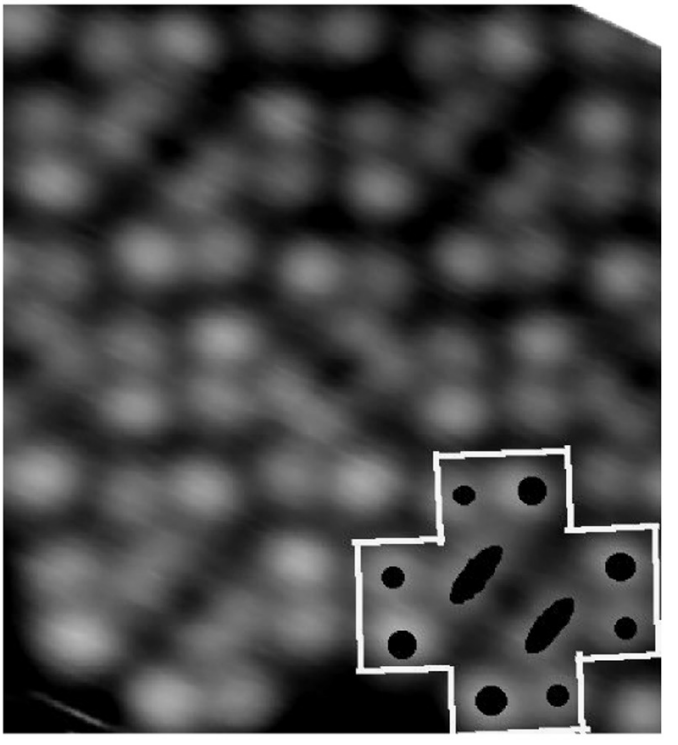

(b)

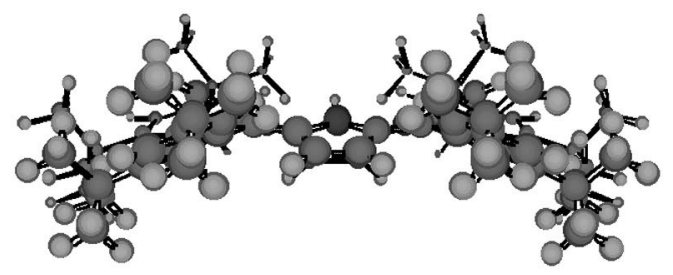

Fig. 4 Calculated macrocyclic conformation of the TBPP molecule using the semiempirical molecular orbital calculations. Top (a) and side (b) views of a calculated conformation with $20^{\circ}$ alternate rotations of the phenyl-porphyrin bonds. A saddle-shaped nonplanar deformation of the central porphyrin is induced by the steric interactions with the rotated phenyl substituents.

に適合するようにフェニル基が回転し，弚れがポルフィ リン環の非平面化を誘起して形成したといえる。同樣の STM 像は, ポルフィリンの中心に銅原子を配位させた $\mathrm{Cu}-\mathrm{TBPP}$ 分子でも得られており, さらにバイアス電圧 による変化もほとんど無いことも確認している。これら の結果は, 得られた STM 像が電子状態ではなく, 非平 面化構造によるものであることを支持する。

さらに蒸着量を増加させると, TBPP 分子は非平面化 構造を保ったまま 2 次元配列した (Fig. 5 (a))。基板温 度が室温であっても巨大な 2 次元島を形成することか ら, $\mathrm{Au}(111)$ 基板上の TBPP 分子の拡散距離は室温で

(b)

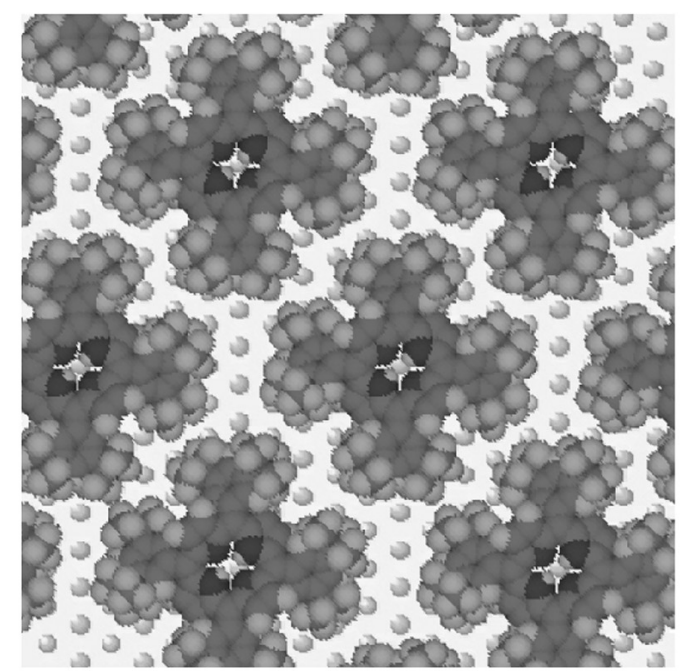

Fig. 5 (a) STM image at $63 \mathrm{~K}$ of a TBPP island formed on the $\mathrm{Au}(111)$ surface. (b) Model of the molecular arrangement of the TBPP molecules on the Au(111)$1 \times 1$ surface, exhibiting $11 \times 5 \sqrt{3}$ superstructure.

も十分長いと考えられる。Fig. 5 (b) に示すように，こ の 2 次元島は TBPP 分子の最密充填配列からなり，兴の 周期は基板構造に整合した $11 \times 5 \sqrt{3}$ 構造であることが わかった。 
ここで興味深いのは, ポルフィリン環の非平面化によ って鏡映 $\left(\mathrm{C}_{2 \mathrm{v}}\right)$ 対称性か誘起され, 兴の配向 (対称軸) がSTM 像の暗線として判別できる点である。2 次元島 の高分解能 STM 像および光のモデルより, 光れ光れの 分子は 2 つ配向を示すことが可能であり, 室温で蒸着 しただけでは光れらは無秩序に分布していることがわか る。この無秩序配向は, $200^{\circ} \mathrm{C}$ 程度の熱アニールによっ て秩序的な配向へと变化した。Fig. 6 (a) と (b) に示 すように, アニール後, 分子配列構造自体に変化はない が, 2 次元島内の分子配向は [112] 方向では揃ってお り，[2111] 方向では 90ずつ回転している (Fig. 6 (b) と (d))。

この配向秩序化は，隣り合ったブチルフェニル基同士 による立体的な分子間相互作用によるものと考えられ

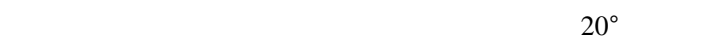
転していることから, 隣り合う分子同士のフェニル基の 回転方向は同一もしくは逆方向の 2 通りがあり得る。秩 序化した配向では, 隣り合うフェニル基の回転は全て逆 方向になっており，互い違いになるように接触している のがわかる。このことから , ブチルフェニル基同士の立 体的相互作用を考えた場合，フェニル基同士が平行に隣
り合うよりも交差して隣り合う方が安定と言える。しか しながら，この相互作用はファン・デル・ワールスカに よるため, 弚のエネルギー差は小さいと考えられる。

\section{3 . シアノ基による選択的自己組織化}

上述のような配向秩序化の結果は, 置換基同士の相互 作用を利用することで, ポルフィリンのような比較的大 きな分子でも表面上での分子配列制御が可能なことを示 している。溶液中で行われている超分子化学では, 選択 的な分子間相互作用として水素結合や配位結合が多く利 用されているが, 本研究では, これらに比べて相互作用 が弱いものの遠達性である双極子相互作用を持つシアノ 基に着目した ${ }^{22}$ 。この置換基を選択した理由は，相互作 用や構造自身が単純であること，強い相互作用を導入し た場合に真空蒸着が難しくなることなどである。

ベンゼン環にシアノ基を導入したシアノベンゼンは， シアノ基内の炭素原子と室素原子の間の分極によって局 所的な双極子が誘起される。关の分子間相互作用を $\mathrm{ab}$ initio 分子軌道計算 (MP 2/6-31 G* ${ }^{*}$ レベル) すると,2 量体を形成する場合はお互いに反対称に向かい合い, 3 量体を形成する場合は環状に結合することがわかる (a)

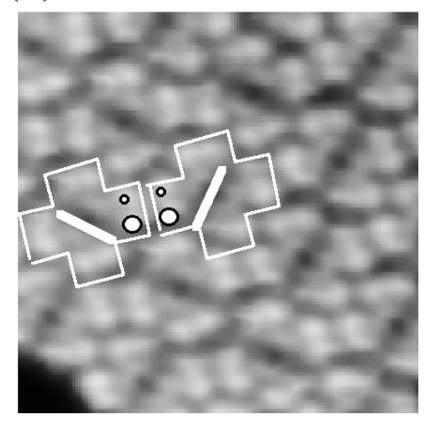

(c)

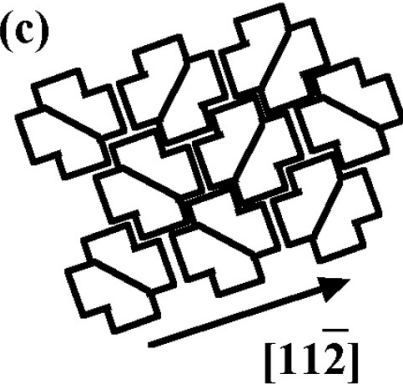

(b)

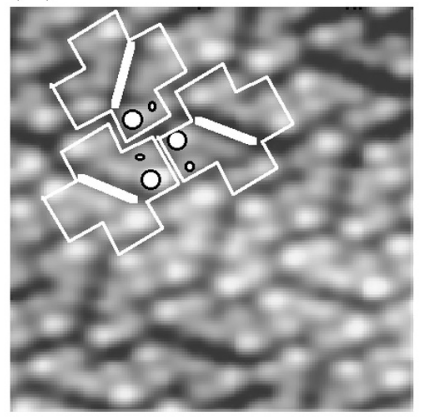

(d)

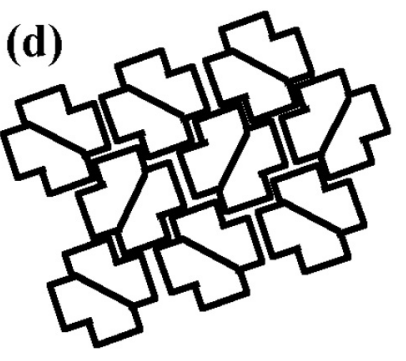

Fig. 6 STM images of TBPP islands before (a) and after (b) thermal annealing at about $470 \mathrm{~K}$ for $1 \mathrm{~min}$. (c) and (d) Schematic illustrations of the molecular arrangement and orientations within islands. 
(Fig. 7)。これらの安定化エネルギ一は，光れ光れ-7.12 $\mathrm{kcal} / \mathrm{mol},-12.40 \mathrm{kcal} / \mathrm{mol}$ となっており, 双極子相互

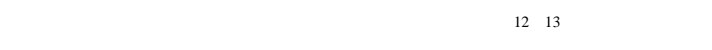
は, シアノ基の窒素原子とベンゼン環の水素原子の間で 弱い水素結合を形成しているためだと考えられる。

このようなシアノベンゼン分子の特徵的な分子間相互 作用をポルフィリン分子に導入するために , Fig. 8 のよ うに TBPP 分子の一部をシアノフェニル基に置き換え た ${ }^{12)}$ 。この場合, 1 個のシアノフェニル基を導入した分 子 (Cyanophenyl-tris (di-tertiarybutylphenyl) porphyrin; CTBPP) は 1 種類に限られるが, 2 個のシアノフェ ニル基を導入した分子 (Bis(cyanophenyl)-bis (ditertiarybutylphenyl) porphyrin; BCTBPP) は光の位置関係 でシス型とトランス型の 2 種類に分類される。

Fig. 9 (a) は CTBPP 分子を $\mathrm{Au}(111)$ 表面に蒸着した
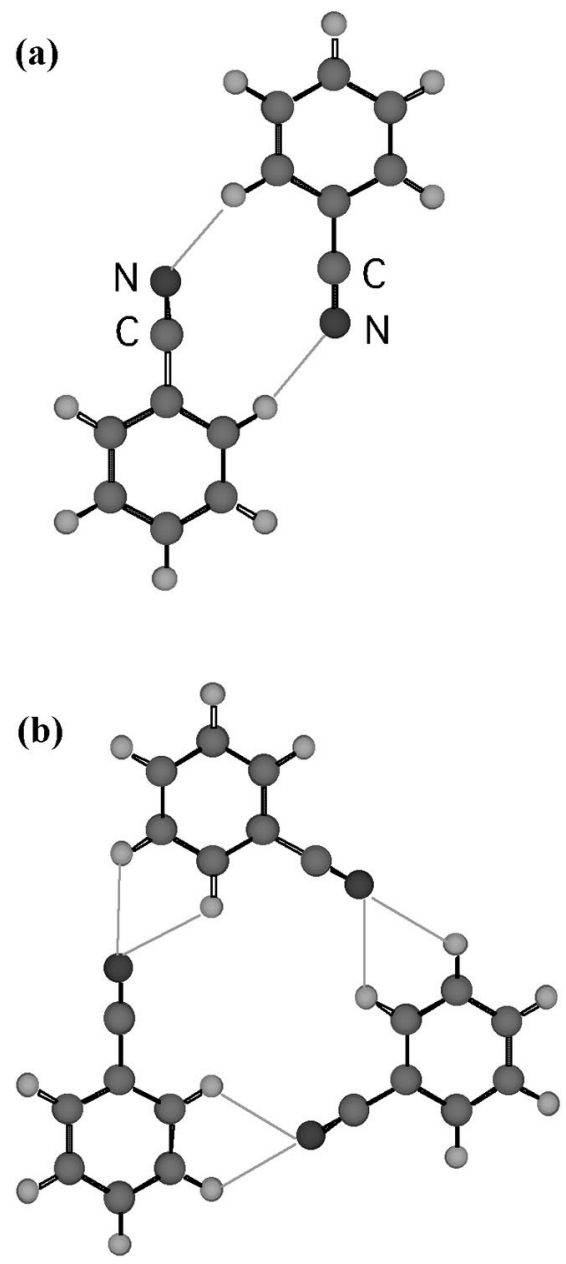

Fig. 7 Calculated molecular aggregations of (a) cyanobenzen dimer and (b) trimer.
後に得られた低温 STM 像である。ほとんどの分子が， ヘリングボーン構造の変曲点に三角形状に配列してい る。光の高分解能像が Fig. 9 (b) であり, 弚れから得 られた分子モデル (Fig. 9 (c)) によって, 中心を向い たシアノ基か環状に配列していることがわかる。この配 列構造はシアノベンゼン分子の 3 量体と全く同樣であ
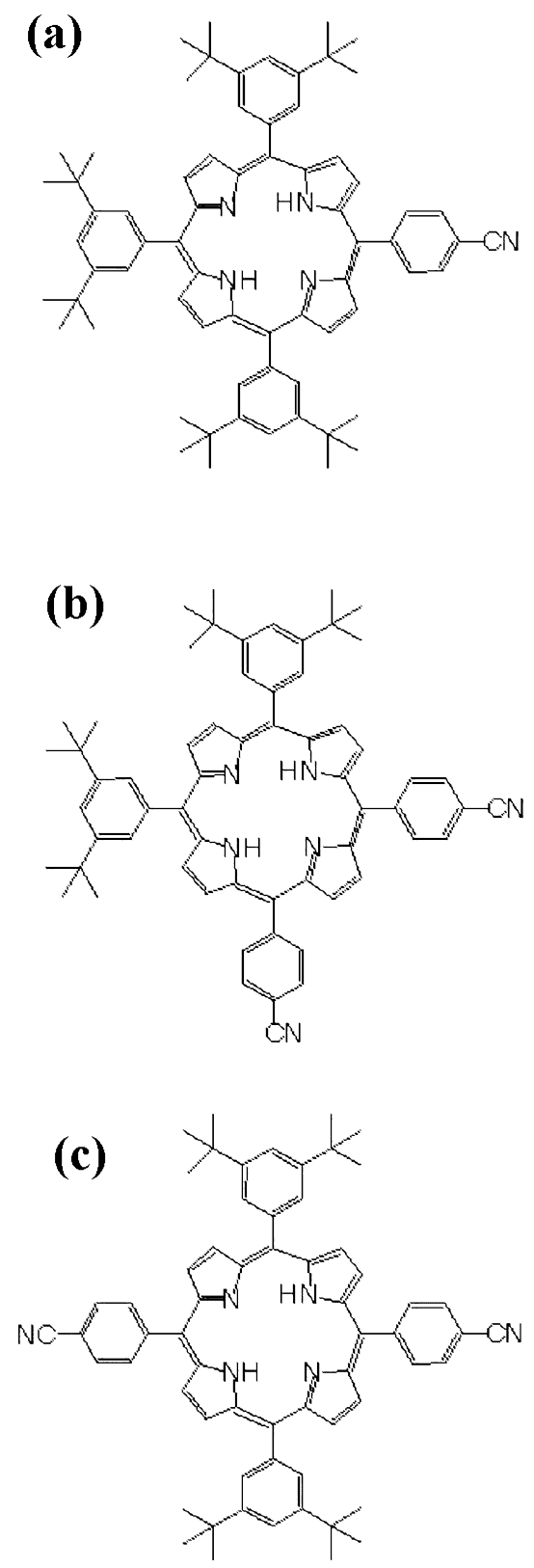

Fig. 8 Structural formula of the cyanophenyl substituted porphyrins (a) CTBPP, (b) cis-BCTBPP, and (c) trans-BCTBPP. 
(a)

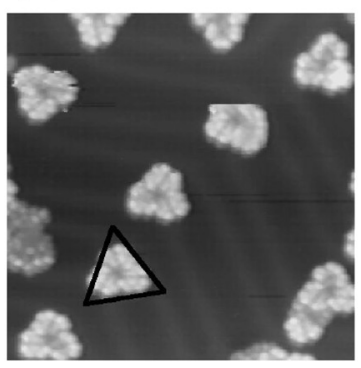

(d)

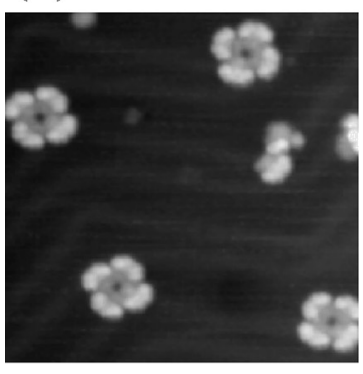

(g)

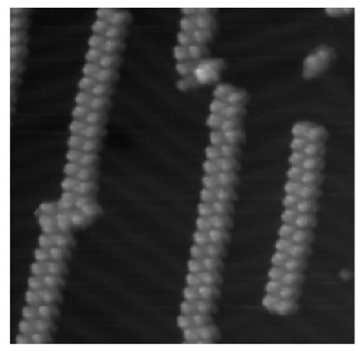

(b)

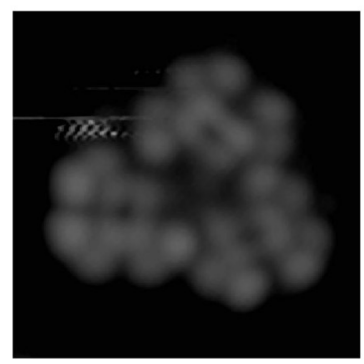

(e)

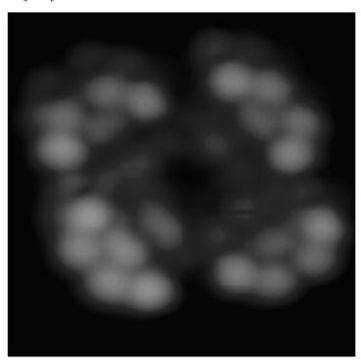

(h)

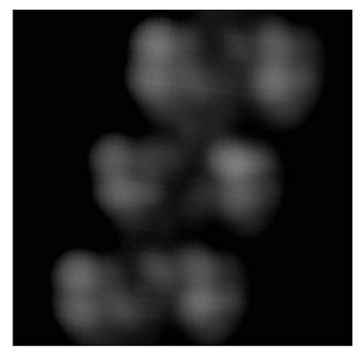

(c)

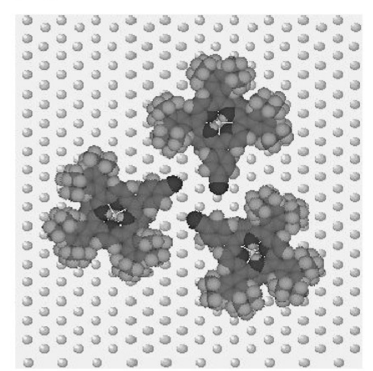

(f)

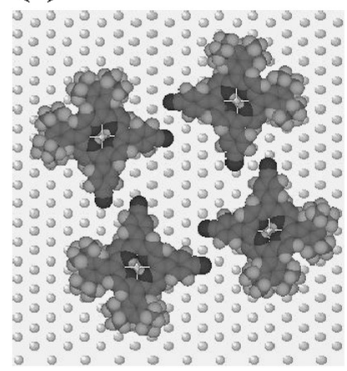

(i)

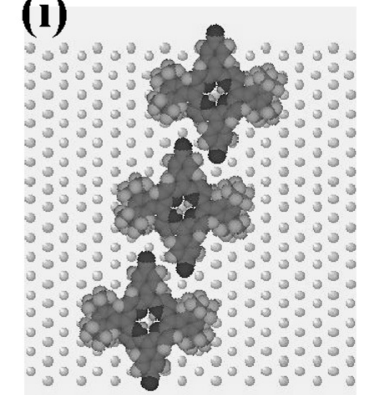

Fig. 9 STM images at $63 \mathrm{~K}$ of CTBPP[(a) and (b)], cis-BCTBPP [(d) and (e)], and trans-BCTBPP [(g) and $(h)$ ]. The corresponding molecular model is for (c) CTBPP, (f) cis-BCTBPP, and (i) transBCTBPP, respectively.

り , シアノフェニル基同士の局所的な相互作用がポルフ イリン分子の選択的な分子会合を実現しているといえ る。

さらに , シス型に 2 個のシアノフェニル基を配置させ た cis-BCTBPP 分子では , 4 個の分子がリング状に配列 した (Fig. 9 (d) と (e))。この会合構造では, シアノ ベンゼン分子の 2 量体と同樣にシアノ基同士がそれぞれ 反対称に配置し，光の4 組の結合で結果的にリング状に なっていることがわかる (Fig.9 (f))。

СТВPP 分子や cis-BCTBPP 分子の場合, 分子クラスタ 一の周囲がブチル基で囲まれるため, 弚れ以上の分子会 合が進まずに決まったサイズに自己制御されるが，両端
にシアノ基を導入した分子 (trans-BCTBPP) では , シア ノ基同士が連鎖的に相互作用し直線状に配列した（Fig. $9(\mathrm{~g}))$ 。この一次元鎖配列もシアノベンゼンの 2 量体配 列と同樣にシアノ基同士が光れ光れ反対称に配置してい る (Fig. 9 (h) と (i))。この自己配列した分子鎖は， 単一分子の幅で最大で $100 \mathrm{~nm}$ 以上にも及っぶ。また, 図 中の分子鎖の配向が一方向に揃っているのは, ヘリング ボーン構造の変曲点に初期吸着した分子同士が優先的に つながったためと考えられる。

$$
\text { 4.ま と め }
$$

以上のように, 局所的な相互作用を持つシアノフェニ 
ル基をポルフィリン分子に導入し，关の位置や数を制御 することによって , 基板表面上で選択的な自己組織化が 可能であることがわかった。置換基による選択的な分子 間相互作用は超分子化学の分野で系統的に調べられてお り，弚のデータベースを利用することでより複雑な分子 ナノ構造制御が基板上で可能になると思われる。また， 溶液中との自由度の違いによって, 基板表面上での特有 な相互作用も期待できる。STM に代表される走査型プ ローブ顕微鏡を用いた局所構造解析によって, 光ういっ た理解が進むと考えられる。

\section{文献}

1) Y. Wada, M. Tsukada, M. Fujihira, K. Matsushige, T. Ogawa, M. Haga and S. Tanaka: Jpn. J. Appl. Phys. 39, 3825 (2000).

2) C. Joachim, J.K. Gimzewski and A. Aviram: Nature 408, 541 (2000).

3) K. Sugiura, H. Tanaka, T. Matsumoto, T. Kawai and Y.
Sakata: Chem. Lett. 1193 (1999).

4) T.A. Jung, R.R. Schlittler, J.K. Gimzewski, H. Tang and C. Joachim: Science 271, 181 (1996).

5) T.A. Jung, R.R. Schlittler and J.K. Gimzewski: Nature 386, 696 (1997).

6) C. Hamai, H. Tanaka and T. Kawai: J. Vac. Sci. Technol. B 17, 1313 (1999).

7) J.-M. Lehn: "Supramolecular Chemistry: Concept and Perspectives" (VCH, Weinheim, 1995).

8) K.M. Kadish, K.M. Smith, R. Guilard (ed): “The Porphyrin Handbook” (Academic Press, San Diego, 2000).

9) 森 正保 “生化学の魔術師一ポルフィリン一”(裳 華房，1990).

10) K. Sugiura, K. Iwasaki, K. Umishita, S. Hino, H. Ogata, S. Miyajima and T. Sakata: Chem. Lett. 841 (1999).

11) T. Yokoyama, S. Yokoyama, T. Kamikado and S. Mashiko: J. Chem. Phys. 115, 3814 (2001).

12) T. Yokoyama, S. Yokoyama, T. Kamikado, Y. Okuno and S. Mashiko: Nature 413, 619 (2001).

13) Y. Okuno, T. Yokoyama, S. Yokoyama, T. Kamikado and S. Mashiko: J. Am. Chem. Soc. 124, 7218 (2002). 